\title{
The development of construction waste production indicators for the Irish construction industry
}

\author{
M. Kelly \& J. Hanahoe \\ Department of Building and Civil Engineering, \\ Galway-Mayo Institute of Technology, Ireland
}

\begin{abstract}
This study has produced unit waste production factors $\left(\mathrm{kg} / \mathrm{m}^{2}\right)$ for new construction in Ireland for 2005. The Environmental Protection Agency (EPA) has estimated that construction and demolition waste (C\&D W) has increased from 1.52 million tonnes in 1995 to 16.28 million tonnes in 2006. These estimates are primarily based on $\mathrm{C} \& \mathrm{D} \mathrm{W}$ quantities received at licensed and permitted facilities throughout the country. An audit methodology was developed and tested on 54 construction projects throughout Ireland over a twoyear period to examine waste production on site. Each project was assessed over a 6-month period providing a 'snapshot' analysis. Average unit waste factors of $70.27 \mathrm{~kg} / \mathrm{m}^{2}$ for new residential construction, $86.82 \mathrm{~kg} / \mathrm{m}^{2}$ for new private nonresidential construction, $138.94 \mathrm{~kg} / \mathrm{m}^{2}$ for new social infrastructure construction and $48.48 \mathrm{~kg} / \mathrm{m}^{2}$ for new productive infrastructure construction were generated. The generation of unit waste production factors for the different construction activities will enable the industry to benchmark their performance and provide indicators for future improvement.
\end{abstract}

Keywords: waste, construction, demolition, composition, quantities, audit, Ireland, indicators, methodology, sustainable, built environment.

\section{Introduction}

The Irish construction industry has experienced unprecedented economic growth over the past fifteen years. Construction output in 2006 was estimated at $€ 35.5$ billion representing 24 per cent of Gross National Product (GNP). In the second 
quarter of 2007, it was estimated that 280300 people were employed directly or indirectly by the construction/civil engineering industry. This accounted for $13.4 \%$ of total employment and $22 \%$ of all jobs created in the previous twelve months [3].

The growth of the construction industry with all its economic benefits also has had some negative environmental impacts. In 2006, it was conservatively estimated that 16.28 million tonnes of C\&D W was produced in Ireland [2]. This represents over half $(55 \%)$ of the total non-agricultural waste generated. This phenomenal increase can be in part but not wholly attributable to improved reporting and the use of different estimation methodologies. None of these methodologies included data on site waste production.

The government has recognised the seriousness of this issue by setting out targets for the construction industry to recycle and/or recover $85 \%$ of this waste stream by 2013 [4]. One of the main difficulties in achieving these targets is the lack of reliable statistics to benchmark C\&D W production in Ireland.

This paper will outline research carried out by the Construction Waste and Built Environment research group at the Galway-Mayo Institute of Technology over a two-year period into the generation of data on C\&D W production on site by:

- Producing unit waste generation factor $\left(\mathrm{kg} / \mathrm{m}^{2}\right)$ for the new construction sector.

- Identifying the main components of the C\&D W stream on site.

- Developing and testing an audit methodology on 54 construction project throughout the country.

\section{Methods}

The main resource in this study was the third-year students of the B.Sc. (Honours) in Construction Management in the Department of Building and Civil Engineering at the Galway-Mayo Institute of Technology. Each year the students must complete a 6-month site placement on a construction/civil engineering project. Each student acted as a point source assessor on his/her work placements measuring waste production on site. This provided a waste production 'snapshot' of 54 projects over a two-year period (2004 and 2005).

Prior to testing on site, it was decided to develop a practical audit methodology incorporating the following key considerations [5]:

- Identification of waste management practices on site including skip management, on-site burning and reuse of materials.

- Selection of a method for measuring the waste. A visual assessment of skip contents was used.

- Classification of the C\&D W categories. This involved a balance between the accuracy required and the number of different waste materials being produced on site.

- Provision of on-site arrangements. This was dependent on the project type and site constraints.

- Analysis of the data to produce the required results e.g. composition and quantity. 
A waste audit book consisting of waste audit sheets (Figure 1) and a supplementary monthly report format was developed and distributed to the students (point source assessors). To ensure reliable data collection, a C\&D W module was developed as part of the construction management curriculum consisting of lectures, workshops and site visits.

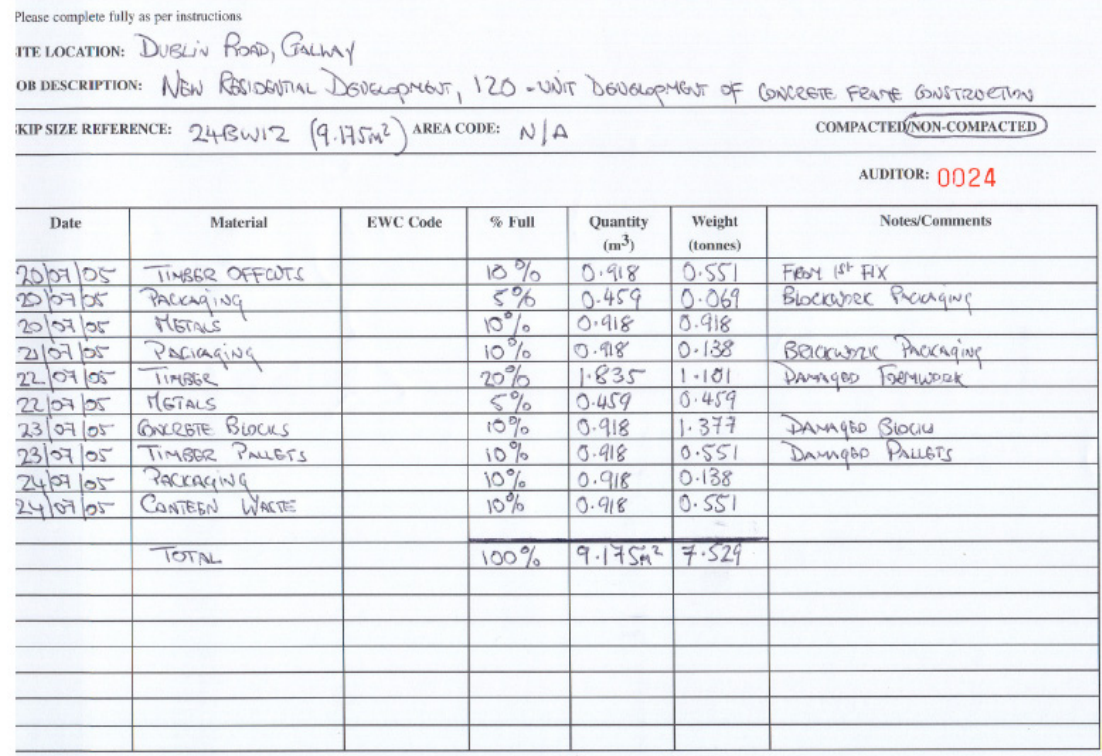

Figure 1: $\quad$ Example of a waste audit sheet.

The methodology was a basic skip analysis using visual assessment to identify and quantify all the materials being taken off site in skips/bins/containers. Each audit sheet recorded the following:

a. Auditor name.

b. Date.

c. Site location including postal address.

d. Project description including project category and method of construction.

e. Skip size reference including skip size and name of supplier.

f. Area code identifying the location of the skips.

g. Compacted/non compacted skip contents.

h. Material description including appropriate European Waste Catalogue (EWC) code [6] if applicable.

i. Percentage full by visual assessment.

j. Conversion from percentages to volume $\left(\mathrm{m}^{3}\right)$.

$\mathrm{k}$. Conversion from volume to weight $\left(\mathrm{m}^{3}\right.$ to $\mathrm{kg}$ ) using the conversion factors provided in the Waste Management (Landfill Levy) Regulations 2002 [7] (Table 1).

1. Notes/comments identifying any waste management practices. 
Table 1: $\quad$ Conversion factors used [7].

\begin{tabular}{|l|c|}
\hline Waste Category & $\mathbf{m}^{\mathbf{3}}$ to tonnes \\
\hline Inactive or inert waste & $\mathrm{x} 1.50$ \\
\hline Paper and plastics & $\mathrm{x} 0.15$ \\
\hline Cardboard, pallets, plasterboard, canteen waste & $\mathrm{x} 0.40$ \\
\hline Timber/wood & $\mathrm{x} 0.60$ \\
\hline Building and construction, mixed C\&D W & $\mathrm{x} 0.60$ \\
\hline Others & $\mathrm{x} 1.00$ \\
\hline
\end{tabular}

This data was collated at the end of each month to produce a monthly report containing the following:

- Name of auditor.

- Project description.

- Total floor area $\left(\mathrm{m}^{2}\right)$.

- Phase of the project.

- Completed floor area $\left(\mathrm{m}^{2}\right)$ at the end of each month.

- The volume of each waste material generated in that month.

- Number of skips/bins/containers taken off site.

- Volume waste factor $\left(\mathrm{m}^{3}\right.$ of C\&D W/m $/ \mathrm{m}^{2}$ of completed floor area).

The submitted data was reviewed each month validating and categorising the factors produced in the monthly reports. The submitted volumes were converted to weights to produce a weight waste factor $\left(\mathrm{kg}\right.$ of $\mathrm{C} \& \mathrm{D} \mathrm{W} / \mathrm{m}^{2}$ of completed floor area). The submission of the monthly reports enhanced the value of the 'snapshot' audits by combining primary data (measurements and causes) and secondary data (demographics such as construction activity, skip sizes and number etc.) to put them in context with the overall framework of the project.

\section{Results}

\subsection{Project categories}

Each project audited was divided into categories as used by the EPA in the National Waste Database Report 2001 [8]:

- New residential (new private and public housing).

- New private non-residential (private and semi-state industry, commercial, agricultural, tourism and worship).

- New productive infrastructure (water and sanitary services, airports, harbours, energy and telecommunications).

- New social infrastructure (education, health, public buildings, local authority services and the Gaeltacht). 


\subsection{Generation of waste production indicators}

Each project 'snapshot' audited was termed a point source assessment (PSA). For each site, the total C\&D W produced $\left(\mathrm{m}^{3}\right)$ was divided by the completed floor area $\left(\mathrm{m}^{2}\right)$ to give the volumetric waste factor $\left(\mathrm{m}^{3} / \mathrm{m}^{2}\right)$. The volume of C\&D W was converted into kilograms using the conversion factors outlined in the Waste Management (Landfill Levy) Regulations 2002 [7]. This figure was then divided by the completed floor area to produce the weight waste factor $\left(\mathrm{kg} / \mathrm{m}^{2}\right)$. A mean was calculated for each category producing the following results:

- The new residential construction category had an average unit waste factor of $70.27 \mathrm{~kg} / \mathrm{m}^{2}$ based on 19 audited projects (Table 2).

- The new private non residential construction category had an average unit waste factor of $86.82 \mathrm{~kg} / \mathrm{m}^{2}$ based on 22 audited projects (Table 3).

Table 2: New residential construction results.

\begin{tabular}{|c|c|c|c|c|c|}
\hline Reference & $\begin{array}{c}\text { Total } \\
\text { Waste } \\
\left(\mathbf{m}^{3}\right)\end{array}$ & $\begin{array}{c}\text { Total } \\
\text { Waste } \\
\text { (tonnes) }\end{array}$ & $\begin{array}{c}\text { Completed } \\
\text { Floor Areas } \\
\left(\mathrm{m}^{2}\right)\end{array}$ & $\begin{array}{c}\text { Waste } \\
\text { Factor } \\
\left(\mathrm{m}^{3} / \mathrm{m}^{2}\right)\end{array}$ & $\begin{array}{l}\text { Waste } \\
\text { Factor } \\
\left(\mathrm{kg} / \mathrm{m}^{2}\right)\end{array}$ \\
\hline PSA 1 & 109.656 & 32.605 & 2850 & 0.039 & 11.440 \\
\hline PSA 2 & 390.920 & 140.703 & 13104 & 0.030 & 10.737 \\
\hline PSA 3 & 200.164 & 135.197 & 9000 & 0.022 & 15.022 \\
\hline PSA 4 & 86.290 & 55.572 & 2800 & 0.031 & 19.847 \\
\hline PSA 5 & 21.910 & 9.155 & 234 & 0.094 & 39.124 \\
\hline PSA6 & 281.010 & 143.720 & 4158 & 0.068 & 34.565 \\
\hline PSA 7 & 197.977 & 81.848 & 2295 & 0.086 & 35.664 \\
\hline PSA 8 & 98.426 & 83.114 & 5400 & 0.018 & 15.391 \\
\hline PSA 9 & 376.850 & 312.570 & 7290 & 0.052 & 42.877 \\
\hline PSA 10 & 210.270 & 144.281 & 454 & 0.463 & 317.800 \\
\hline PSA 11 & 755.270 & 577.124 & 2000 & 0.378 & 288.562 \\
\hline PSA 12 & 102.542 & 63.276 & 960 & 0.107 & 65.913 \\
\hline PSA 13 & 164.267 & 63.369 & 1375 & 0.119 & 46.087 \\
\hline PSA 14 & 37.612 & 25.515 & 1375 & 0.027 & 18.556 \\
\hline PSA 15 & 297.569 & 210.958 & 2057 & 0.145 & 102.556 \\
\hline PSA 16 & 89.799 & 65.240 & 486 & 0.185 & 134.239 \\
\hline PSA 17 & 504.467 & 435.579 & 6942 & 0.073 & 62.745 \\
\hline PSA 18 & 117.630 & 59.335 & 1688 & 0.070 & 35.151 \\
\hline PSA 19 & 736.530 & 832.588 & 21400 & 0.034 & 38.906 \\
\hline Totals & 4799.159 & 3471.749 & 85868 & 2.041 & 1335.182 \\
\hline \multicolumn{5}{|c|}{$\begin{array}{l}\text { Total weight waste factors }\left(\mathrm{kg} / \mathrm{m}^{2}\right) / \mathrm{no} \text {. of sites }=1335.180 / 19 \\
=\end{array}$} & $\begin{array}{r}70.27 \\
\mathrm{~kg} / \mathrm{m}^{2}\end{array}$ \\
\hline \multicolumn{5}{|c|}{ Total volume waste factor $\left(\mathrm{m}^{3} / \mathrm{m}^{2}\right) /$ no. of sites $=2.041 / 19=$} & $\begin{array}{l}0.107 \\
\mathbf{m}^{3} \mathrm{~m}^{2}\end{array}$ \\
\hline
\end{tabular}


- The new social infrastructure construction category had an average unit waste factor of $138.94 \mathrm{~kg} / \mathrm{m}^{2}$ based on nine audited projects (Table 4).

- The new productive infrastructure construction category had an average unit waste factor of $48.48 \mathrm{~kg} / \mathrm{m}^{2}$ based on three audit projects (Table 5).

Table 3: $\quad$ New private non-residential construction results.

\begin{tabular}{|c|c|c|c|c|c|}
\hline Reference & $\begin{array}{c}\text { Total Waste } \\
\left(\mathrm{m}^{3}\right)\end{array}$ & $\begin{array}{c}\text { Total } \\
\text { Waste } \\
\text { (tonnes) }\end{array}$ & $\begin{array}{l}\text { Completed } \\
\text { Floor } \\
\text { Areas }\left(\mathrm{m}^{2}\right)\end{array}$ & $\begin{array}{l}\text { Waste } \\
\text { Factor } \\
\left(\mathrm{m}^{3} / \mathrm{m}^{2}\right)\end{array}$ & $\begin{array}{l}\text { Waste } \\
\text { Factor } \\
\left(\mathrm{kg} / \mathrm{m}^{2}\right)\end{array}$ \\
\hline PSA 1 & 221.000 & 86.060 & 4391 & 0.050 & 19.599 \\
\hline PSA 2 & 663.500 & 442.065 & 14300 & 0.046 & 30.914 \\
\hline PSA 3 & 1163.040 & 689.597 & 16920 & 0.069 & 40.756 \\
\hline PSA 4 & 415.600 & 272.820 & 5227 & 0.080 & 52.194 \\
\hline PSA 5 & 80.650 & 45.453 & 576 & 0.140 & 78.911 \\
\hline PSA 6 & 137.800 & 87.665 & 880 & 0.157 & 99.619 \\
\hline PSA 7 & 320.000 & 218.190 & 2000 & 0.160 & 109.095 \\
\hline PSA 8 & 351.800 & 239.720 & 1814 & 0.194 & 132.145 \\
\hline PSA 9 & 980.300 & 837.595 & 5670 & 0.173 & 147.724 \\
\hline PSA 10 & 276.300 & 369.505 & 2200 & 0.126 & 167.957 \\
\hline PSA 11 & 455.150 & 266.206 & 900 & 0.506 & 295.784 \\
\hline PSA 12 & 282.910 & 201.362 & 700 & 0.404 & 287.660 \\
\hline PSA 13 & 480.015 & 230.383 & 7820 & 0.061 & 29.461 \\
\hline PSA 14 & 59.346 & 48.730 & 1725 & 0.034 & 28.249 \\
\hline PSA 15 & 71.223 & 37.301 & 400 & 0.178 & 93.253 \\
\hline PSA 16 & 414.758 & 233.749 & 5090 & 0.082 & 45.923 \\
\hline PSA 17 & 139.560 & 132.490 & 5456 & 0.026 & 24.283 \\
\hline PSA 18 & 20.873 & 11.237 & 900 & 0.023 & 12.486 \\
\hline PSA 19 & 34.563 & 18.959 & 867 & 0.040 & 21.867 \\
\hline PSA 20 & 344.276 & 239.842 & 2256 & 0.153 & 106.313 \\
\hline PSA 21 & 26.618 & 9.270 & 285 & 0.093 & 32.526 \\
\hline PSA 22 & 300.856 & 182.430 & 3425 & 0.088 & 53.264 \\
\hline Totals & 7240.138 & 4900.629 & 83802.000 & 2.883 & 1909.983 \\
\hline \multicolumn{5}{|c|}{ Total weight waste factors $\left(\mathrm{kg} / \mathrm{m}^{2}\right) / \mathrm{no}$ of sites $=1909.983 / 22$} & $\begin{array}{l}86.82 \\
\mathrm{~kg} / \mathrm{m}^{2} \\
\end{array}$ \\
\hline \multicolumn{5}{|c|}{ Total volume waste factors $\left(\mathrm{kg} / \mathrm{m} 2^{2}\right) / \mathrm{no}$. of sites $=2.883 / 22$} & $\begin{array}{l}0.131 \\
\mathrm{~m}^{3} / \mathrm{m}^{2}\end{array}$ \\
\hline
\end{tabular}

\subsection{Composition of 'snapshot' point source assessments}

The composition of $\mathrm{C} \& \mathrm{D} \mathrm{W}$ varied according to project type/activity. The identification of the individual waste components is essential in establishing waste prevention and minimisation targets. The methodology used aimed to 
Table 4: $\quad$ New social infrastructure construction results.

\begin{tabular}{|c|c|c|c|c|c|}
\hline Reference & $\begin{array}{c}\text { Total } \\
\text { Waste } \\
\left(\mathbf{m}^{3}\right)\end{array}$ & $\begin{array}{c}\text { Total } \\
\text { Waste } \\
\text { (tonnes) } \\
\end{array}$ & $\begin{array}{c}\text { Completed } \\
\text { Floor } \\
\text { Areas }\left(\mathbf{m}^{2}\right)\end{array}$ & $\begin{array}{l}\text { Waste } \\
\text { Factor } \\
\left(\mathrm{m}^{3} / \mathbf{m}^{2}\right)\end{array}$ & $\begin{array}{c}\text { Waste } \\
\text { Factor } \\
\left(\mathrm{kg} / \mathbf{m}^{2}\right)\end{array}$ \\
\hline PSA 1 & 53.500 & 34.650 & 2080 & 0.026 & 16.659 \\
\hline PSA 2 & 120.169 & 97.965 & 5780 & 0.021 & 16.949 \\
\hline PSA 3 & 356.750 & 271.415 & 6853 & 0.052 & 39.605 \\
\hline PSA 4 & 289.620 & 119.538 & 1817 & 0.159 & 65.789 \\
\hline PSA 5 & 164.000 & 144.640 & 404 & 0.406 & 358.020 \\
\hline PSA6 & 124.413 & 86.947 & 328 & 0.379 & 265.082 \\
\hline PSA 7 & 150.531 & 88.543 & 2584 & 0.058 & 34.266 \\
\hline PSA 8 & 468.500 & 351.216 & 1344 & 0.349 & 261.321 \\
\hline PSA 9 & 613.080 & 399.288 & 2071 & 0.296 & 192.800 \\
\hline Totals & 2340.563 & 1594.202 & 23261 & 1.746 & 1250.491 \\
\hline \multicolumn{5}{|c|}{$\begin{array}{l}\text { Total weight waste factors }\left(\mathrm{kg} / \mathrm{m}^{2}\right) / \mathrm{no} . \text { of } \text { sites }=1 \\
250.491 / 9\end{array}$} & $138.94 \mathrm{~kg} / \mathrm{m}^{2}$ \\
\hline \multicolumn{5}{|c|}{ Total volume waste factors $\left(\mathrm{m} 3 / \mathrm{m}^{2}\right) / \mathrm{no}$ of sites $=1.746 / 9$} & $0.194 \mathrm{~m} 3 / \mathrm{m}^{2}$ \\
\hline
\end{tabular}

Table 5: $\quad$ New productive infrastructure construction results.

\begin{tabular}{|c|c|c|c|c|c|}
\hline Reference & $\begin{array}{c}\text { Total } \\
\text { Waste } \\
\left(\mathbf{m}^{3}\right)\end{array}$ & $\begin{array}{c}\text { Total } \\
\text { Waste } \\
\text { (tonnes) }\end{array}$ & $\begin{array}{l}\text { Completed } \\
\text { Floor } \\
\text { Areas }\left(\mathrm{m}^{2}\right)\end{array}$ & $\begin{array}{c}\text { Waste } \\
\text { Factor } \\
\left(\mathrm{m}^{3} / \mathrm{m}^{2}\right)\end{array}$ & $\begin{array}{c}\text { Waste } \\
\text { Factor } \\
\left(\mathrm{kg} / \mathrm{m}^{2}\right)\end{array}$ \\
\hline PSA 1 & 54.133 & 23.222 & 295 & 0.184 & 78.719 \\
\hline PSA 2 & 84.413 & 54.387 & 975 & 0.087 & 55.782 \\
\hline PSA 3 & 51.768 & 25.673 & 2349 & 0.022 & 10.929 \\
\hline Totals & 190.314 & 103.282 & 3619 & 0.293 & $\mathbf{1 4 5 . 4 3 0}$ \\
\hline \multicolumn{5}{|c|}{ Total weight waste factors $\left(\mathrm{kg} / \mathrm{m}^{2}\right) / \mathrm{no}$. of sites $=145.430 / 3$} & $48.48 \mathrm{~kg} / \mathrm{m}^{2}$ \\
\hline \multicolumn{5}{|c|}{ Total volume waste factors $\left(\mathrm{m}^{3} / \mathrm{m}^{2}\right) / \mathrm{no}$ of sites $=0.292 / 3$} & $0.098 \mathrm{~m} 3 / \mathrm{m}^{2}$ \\
\hline
\end{tabular}

identify the composition by utilising the appropriate EWC codes [6] combined with a general material description. This produced nine main categories as follows:

- Inert waste (excluding excavated materials).

- Paper, plastics and packaging.

- Timber/wood.

- Plasterboard.

- Canteen waste.

- Building and construction/mixed C\&D W.

- Metals (including their alloys).

- Insulation materials.

- Miscellaneous waste. 
It should be noted that no excavated material i.e. soil and stones, was included in the results as none were placed in the skip. The inert waste category recorded consists of materials such as concrete, blocks, brick, tiles and ceramics.

\subsubsection{Composition results}

The composition was expressed in volumes as this identified the waste fractions that occupied the most space in the skips. The biggest contributors in the overall composition of all the audited projects (Figure 2) were: timber/wood (28\%); paper, plastics and packaging (17\%); inert waste (16\%); metals $(13 \%)$ and building \& construction mixed waste $(11 \%)$.

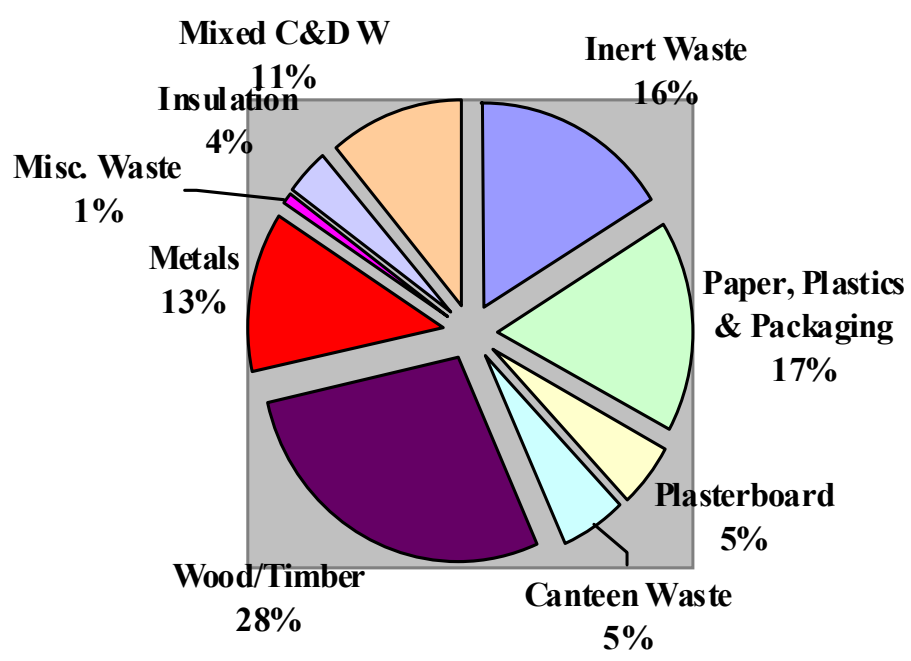

Figure 2: $\quad$ Total project category composition by volume $\left(\mathrm{m}^{3}\right)$.

Each individual category followed a similar trend with:

- Wood, inert waste and paper, plastics and packaging accounting for $66 \%$ of total waste produced in the new residential construction category.

- Wood, metals and paper, plastics and packaging accounting for $65 \%$ of total waste produced in the new private non-residential construction category.

- Wood, mixed C\&D W and paper, plastics and packaging accounting for $68 \%$ of total waste produced in the new social infrastructure construction category.

- Wood, paper, plastics and packaging and miscellaneous waste accounting for $73 \%$ of total waste produced in the new productive infrastructure category. 


\section{Limitations}

The main aim of this study was to produce C\&D W production indicators for new construction in Ireland. 'Snapshot' audits were carried out on 54 projects during 2004 and 2005 generating average waste production indicators for new construction. The main limitations of the study were as follows:

- Each audit was a 'snapshot' measurement of a project over a six month period with the majority of projects at different phases in the construction process. This affected the results where a project in the initial stages had negligible amounts of C\&D W (excluding excavated materials) as opposed to a project $50 \%$ completed.

- The number of sites audited (particularly in the new productive infrastructure category) was insufficient to provide a high degree of statistical confidence especially in the presence of some extreme observations in each category. The audits should continue to generate larger sampling sizes for each category thereby increasing the statistical confidence in the results.

- The unreliability of the conversion factors used. The original function of the conversion factors as outlined in the Waste Management (Landfill Levy) Regulations 2002 [7] was to enable landfill operators calculate the amount of landfill levy payable on certain materials. They are not specific to the $\mathrm{C} \& \mathrm{D} \mathrm{W}$ stream. This was examined on a new social infrastructure project in the Galway region where a comparison was made between the application of the conversion factors to a visual audit and the actual total weight of the same skips weighed at a waste transfer facility [9]. The total weight of the skips weighed on the waste transfer facility's weighbridge was 71.40 tonnes. The visual audit and application of conversion factors yielded a total weight of 230.35 tonnes, nearly three times the actual recorded weight.

- The use of visual assessment and the estimation of waste bulking or air voids. The auditors had to estimate the variation in the consistency of the skip's total contents by considering: the degree of compaction the waste has undergone (if any); the poor placement of waste materials creating air voids; the irregular consistency of some waste types; and the irregular shape of some waste containers.

- The accuracy of the visual assessment is totally reliant on the expertise and diligence of the auditor. Coventry et al. [10] has found that a close correlation can be achieved in visual skip contents when compared to actual skip contents, demonstrating that an experienced auditor can make accurate measurements.

\section{Conclusion}

The generation of $C \& D$ waste production indicators based on Irish construction projects will enable the industry to benchmark their current waste management performance and set targets for future improvement. It is recommended that the methodology discussed in this paper be further developed and used so that the 
construction industry can voluntarily audit their own activities, thereby producing accurate and reliable statistics.

\section{Acknowledgements}

The study was funded by the Environmental Protection Agency under the Environmental Research Technological Development and Innovation (ERDTI) Programme 2000-2006. The assistance of Dr. Shane Colgan of the Environmental Protection Agency; the students of the B.Sc. 3 in Construction Management (2004 \& 2005) and all the participating contractors is acknowledged.

\section{References}

[1] Environmental Protection Agency (2006) National Waste Report 2005, Environmental Protection Agency, Johnstown Caste, Co. Wexford, Ireland.

[2] Environmental Protection Agency (2008) National Waste Report 2006, Environmental Protection Agency, Johnstown Caste, Co. Wexford, Ireland.

[3] DKM Consultants (2007) Review of the Construction Industry 2006 and Outlook 2007-2009, Department of the Environment, Heritage and Local Government, Construction Policy and NDP Co-ordination Unit, Custom House, Dublin 1, Ireland.

[4] Department of the Environment, Heritage and Local Government (2008) Waste Management: Changing Our Ways, Department of the Environment, Heritage and Local Government, Custom House, Dublin 1, Ireland.

[5] Patterson, C.J. (1999) Guide for Construction Waste Audits, Prepared for the Resource Recovery Unit, Auckland Regional Council, New Zealand.

[6] Environmental Protection Agency (2002) European Waste Catalogue and Hazardous Waste List, Environmental Protection Agency, Johnstown Castle, Co. Wexford, Ireland.

[7] Department of the Environment, Heritage and Local Government (2002) S.I. No. 86 of 2002, Waste Management (Landfill Levy) Regulations, 2002, Department of the Environment, Heritage and Local Government, Custom House, Dublin 1, Ireland.

[8] Environmental Protection Agency (2003) National Waste Database Report 2001, Environmental Protection Agency, Johnstown Castle, Co. Wexford, Ireland.

[9] Grimes, D. (2005) The Assessment of Construction and Demolition Waste Arising on Selected Case Study Construction Projects in the Galway Region, Submitted in fulfilment of the requirements of the M.Sc. (Research) in Construction Management in the Department of Building and Civil Engineering at the Galway-Mayo Institute of Technology, Dublin Road, Galway, Ireland.

[10] Coventry, S.; Shorter, S and Kingsley, M. (2001) Demonstrating waste minimisation benefits in construction, Construction Industry Research and Information Association (CIRIA), 6 Storey's Gate, Westminster, London SW1P 3AU, UK. 